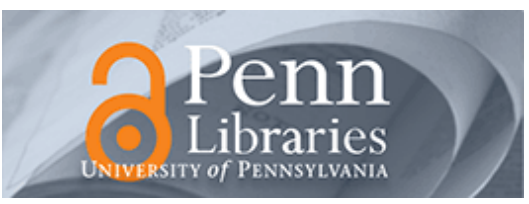

University of Pennsylvania ScholarlyCommons

June 2002

\title{
Fabrication of Highly Porous Yttria-Stabilized Zirconia by Acid Leaching Nickel from a Nickel-Yttria-Stabilized Zirconia Cermet
}

Hyuk Kim

University of Pennsylvania

Calvin da Rosa

University of Pennsylvania

Marta Boaro

University of Pennsylvania

John M. Vohs

University of Pennsylvania, vohs@seas.upenn.edu

Raymond J. Gorte

University of Pennsylvania, gorte@seas.upenn.edu

Follow this and additional works at: https://repository.upenn.edu/cbe_papers

\section{Recommended Citation}

Kim, H., da Rosa, C., Boaro, M., Vohs, J. M., \& Gorte, R. J. (2002). Fabrication of Highly Porous YttriaStabilized Zirconia by Acid Leaching Nickel from a Nickel-Yttria-Stabilized Zirconia Cermet. Retrieved from https://repository.upenn.edu/cbe_papers/13

Copyright The American Ceramic Society. Reprinted from Journal of the American Ceramic Society, Volume 85, Issue 6, June 2002, pages 1473-1476.

Publisher URL: http://www.ceramicjournal.org/issues/v85n6/pdf/7402.pdf

This paper is posted at ScholarlyCommons. https://repository.upenn.edu/cbe_papers/13

For more information, please contact repository@pobox.upenn.edu. 


\title{
Fabrication of Highly Porous Yttria-Stabilized Zirconia by Acid Leaching Nickel from a Nickel-Yttria-Stabilized Zirconia Cermet
}

\author{
Abstract \\ Porous $\mathrm{Y}_{2} \mathrm{O}_{3}$-stabilized $\mathrm{ZrO}_{2}$ ( $\mathrm{YSZ}$ ) samples were synthesized by preparing $\mathrm{NiO} / \mathrm{YSZ}$ composites by tape \\ casting and calcining at $1800 \mathrm{~K}$, reducing the $\mathrm{NiO}$ to nickel in $\mathrm{H}_{2}$ at $973 \mathrm{~K}$, and finally leaching the nickel \\ out of the structure with $2.2 \mathrm{M} \mathrm{HNO}_{3}$ at $353 \mathrm{~K}$. Porous $\mathrm{YSZ}$ was prepared from NiO/YSZ composites \\ containing $0,20,40$, and $50 \mathrm{wt} \% \mathrm{NiO}$. Complete removal of the nickel was demonstrated by XRD, weight \\ changes, and porosity increases. Porosities $>75 \%$ could be achieved without structural collapse of the \\ YSZ phase. Finally, the method was applied to the fabrication of a solid oxide fuel cell with a copper- \\ based anode operating on $\mathrm{H}_{2}$ and $n$-butane.

\section{Comments} \\ Copyright The American Ceramic Society. Reprinted from Journal of the American Ceramic Society, \\ Volume 85, Issue 6, June 2002, pages 1473-1476. \\ Publisher URL: http://www.ceramicjournal.org/issues/v85n6/pdf/7402.pdf
}




\title{
Fabrication of Highly Porous Yttria-Stabilized Zirconia by Acid Leaching Nickel from a Nickel-Yttria-Stabilized Zirconia Cermet
}

\author{
Hyuk Kim, Calvin da Rosa, Marta Boaro, John M. Vohs, and Raymond J. Gorte* \\ Department of Chemical Engineering, University of Pennsylvania, Philadelphia, Pennsylvania 19104
}

\begin{abstract}
Porous $\mathrm{Y}_{2} \mathrm{O}_{3}$-stabilized $\mathrm{ZrO}_{2}$ (YSZ) samples were synthesized by preparing $\mathrm{NiO} / \mathrm{YSZ}$ composites by tape casting and calcining at $1800 \mathrm{~K}$, reducing the $\mathrm{NiO}$ to nickel in $\mathrm{H}_{2}$ at $973 \mathrm{~K}$, and finally leaching the nickel out of the structure with $2.2 \mathrm{M} \mathrm{\textrm {HNO } _ { 3 }}$ at $353 \mathrm{~K}$. Porous YSZ was prepared from NiO/YSZ composites containing $0,20,40$, and $50 \mathrm{wt} \% \mathrm{NiO}$. Complete removal of the nickel was demonstrated by XRD, weight changes, and porosity increases. Porosities $>75 \%$ could be achieved without structural collapse of the YSZ phase. Finally, the method was applied to the fabrication of a solid oxide fuel cell with a copper-based anode operating on $\mathrm{H}_{2}$ and $n$-butane.
\end{abstract}

\section{Introduction}

$\mathrm{P}$ OROus ceramics have many applications, such as fuel-cell electrodes. ${ }^{1}$ In our own work developing copper-based, ceramic-metallic (cermet) composites for direct oxidation of hydrocarbon fuels in solid oxide fuel cells (SOFCs), ${ }^{2-4}$ the synthesis of a porous $\mathrm{Y}_{2} \mathrm{O}_{3}$-stabilized $\mathrm{ZrO}_{2}$ (YSZ) matrix is the first step in fabrication. Unlike traditional Ni-YSZ cermets, which can be formed simply by cosintering $\mathrm{NiO}$ and YSZ powders and subsequently reducing $\mathrm{NiO}$ to nickel, it is difficult to cosinter mixtures of $\mathrm{CuO}_{x}$ and $\mathrm{YSZ}$ powders because $\mathrm{Cu}_{2} \mathrm{O}$ and $\mathrm{CuO}$ melt at temperatures below those necessary for YSZ sintering. To avoid this problem, we have prepared $\mathrm{Cu}$-YSZ cermets by impregnating soluble salts of copper into a porous YSZ structure after the YSZ has been sintered. ${ }^{4,5}$ Because the cermet anode should be $\sim 50 \%$ metal to ensure electronic conductivity and should still remain highly porous to allow diffusion of fuel to the electrolyte interface, high initial porosity is desirable for the YSZ before the addition of $\mathrm{CuO}_{x}$.

There are several standard methods for preparing porous ceramics. Most commonly, the porous structures are produced by sintering powders made up of different particle sizes. ${ }^{6}$ In this case, a porous network is formed by the spaces between the necked powders, and it is difficult to achieve porosities greater than $\sim 40 \%-50 \%$. These porosities can be increased through the use of fibrous materials. ${ }^{7}$ Higher porosities can be achieved through the use of pore formers in tape casting or similar technologies. ${ }^{8-10}$ Here, sacrificial compounds, such as graphite or starch, are added to the green body and are removed during calcination, leaving behind a porous ceramic. Our own experience with this method has shown that the pore sizes in the final ceramic parts are not related to the particle sizes of the pore formers in a simple manner and that the porosity of the ceramic parts depends on the particle size distribution of the ceramic powder, implying that the process of inducing porosity is difficult to control. ${ }^{4}$ Finally, very high porosities can be achieved in reticulate foams. ${ }^{11}$

R. A. Cutler-contributing editor

Manuscript No. 187402. Received October 25, 2001; approved January 25, 2002. Supported by the Office of Naval Research.

${ }^{*}$ Member, American Ceramic Society.
We describe another method for the fabrication of porous ceramics through the use of "oxide" pore formers. The method involves cosintering two oxides that do not form solid solutions, then removing one of the components by selective leaching. In the present work, $\mathrm{NiO}$ is used as the "pore former" in YSZ, and nitric acid is used to selectively leach nickel from the structure. While the use of oxide pore formers requires additional synthesis steps compared with the use of sacrificial pore formers, the fact that $\mathrm{NiO}$ remains in the ceramic product after calcination when the ceramic structure has been established implies that this method of preparing porous YSZ has the potential to produce a much more controlled pore structure. Because a great deal of work has gone into optimizing the oxide and metal domain sizes in Ni-YSZ composites, much is already known about this system. ${ }^{12,13}$ In addition to describing a method for making porous YSZ, we also show that a Ni-YSZ cermet can be converted to a $\mathrm{Cu}$-YSZ cermet. Because cermet-supported YSZ films are unaffected by acid leaching, anode-supported fuel cells with copper-based anodes can be produced in this manner.

\section{Experimental Procedures}

In this study, $\mathrm{NiO} / \mathrm{YSZ}$ composites were prepared by tape casting using $\mathrm{YSZ}\left(\mathrm{ZrO}_{2}, 8 \% \mathrm{Y}_{2} \mathrm{O}_{3}, 0.2 \mu \mathrm{m}\right.$; Tosoh, Tokyo, Japan) and $\mathrm{NiO}$ (Alpha Aesar, Ward Hill, MA) powders asreceived. The powders were mixed to form an aqueous slurry containing binders (B-1000 and B-1014, Duramax, Rohm and Haas, Philadelphia, PA) and a dispersant (D-3021, Duramax, Rohm and Haas). The relative amounts of B-1000, B-1014, and D-3021 compared with the total amount of oxides were $0.48,0.24$, and $0.09 \mathrm{~mL} / \mathrm{g}$, respectively. ${ }^{14}$ Graphite $(325 \mathrm{mesh}$; Alfa Products, Danvers, MA) was also added to the slurry in a quantity equal to $20 \%$ of the total weight of oxides. Tapes were produced to achieve $0.2 \mathrm{~cm}$ plates with final $\mathrm{NiO} / \mathrm{YSZ}$ compositions of $0,20,40$, and $50 \mathrm{wt} \% \mathrm{NiO}$.

After calcining the green tapes to $1800 \mathrm{~K}$ in air using a $2 \% \mathrm{~min}$ temperature ramp, $\sim 0.5 \mathrm{~g}$ of each sample were reduced in $\mathrm{H}_{2}$ at $973 \mathrm{~K}$ for $10 \mathrm{~h}$ to convert the $\mathrm{NiO}$ into nickel. The nickel was removed from the $\mathrm{Ni}$-YSZ cermets by acid leaching, taking advantage of the fact that $\mathrm{ZrO}_{2}$ is extremely insoluble in acid solutions. Approximately $0.5 \mathrm{~g}$ of Ni-YSZ wafers were placed in $50 \mathrm{~mL}$ of $2.2 \mathrm{M} \mathrm{HNO}_{3}$ at $353 \mathrm{~K}$ for $2 \mathrm{~h}$. While it is unclear why reduction of the $\mathrm{NiO}$ was important, we observed that leaching of nickel from the unreduced samples was unacceptably slow.

In all cases, sample weights were measured before and after acid leaching. The porosities of each sample, before and after acid leaching, were also measured using water immersion. This method involved measuring the weights of the dry and water-saturated samples. To ensure saturation, the samples were immersed in boiling water and allowed to cool in water before weighing. Porosities measured by this method were reproducible within $1 \%$ and were shown in past work to be in good agreement with porosities from mercury porosimetry. ${ }^{14}$ Finally, the porosities and pore structures of the two samples were measured using mercury porosimetry (Micromeritics Instrument Corp., Norcross, GA).

A fuel cell with a copper-based anode was also prepared by this method. In the initial step, a two-layer tape was cast in which one 
side contained only YSZ powder, while the other side contained a 1:1 mixture of $\mathrm{NiO}$ and YSZ with $20 \%$ graphite. After calcining the green tape to $1800 \mathrm{~K}$, one side of the ceramic wafer was dense YSZ, $60 \mu \mathrm{m}$ thick, and the other side was a porous NiO/YSZ composite, $400 \mu \mathrm{m}$ thick. After reducing the sample in $\mathrm{H}_{2}$ and leaching out the nickel, a 1:1 mixture of YSZ and $\mathrm{Sr}-\mathrm{LaMnO}_{3}$ (Praxair Surface Technologies, Woodinville, WA) was painted onto the dense side of the wafer and sintered to $1500 \mathrm{~K}$ to form the cathode. $\mathrm{CeO}_{2}$ and copper were added to the porous layer by wet impregnation of $\mathrm{Ce}\left(\mathrm{NO}_{3}\right) \cdot 6 \mathrm{H}_{2} \mathrm{O}$ (Fisher Scientific Co., Pittsburgh, $\mathrm{PA}$ ) and $\mathrm{Cu}\left(\mathrm{NO}_{3}\right)_{3} \cdot 6 \mathrm{H}_{2} \mathrm{O}$ (Alpha Aesar) solutions, then heated in air at $750 \mathrm{~K}$ to decompose the nitrates, as discussed in other publications. ${ }^{4}$ The final anode concentration was $10 \mathrm{wt} \% \mathrm{CeO}_{2}$ and $40 \mathrm{wt} \%$ copper. A platinum wire and mesh were attached to the cathode, and a gold wire was pasted onto the anode with gold paint. Finally, the cell was sealed onto an $\alpha-\mathrm{Al}_{2} \mathrm{O}_{3}$ tube and tested using procedures described elsewhere. ${ }^{2-5}$

\section{Results and Discussion}

Evidence for removal of the nickel from the Ni-YSZ cermets could be observed visually. After calcination, all the NiO/YSZ ceramic wafers were green in color, indicating the presence of the $\mathrm{NiO}$. Reduction in $\mathrm{H}_{2}$ at $973 \mathrm{~K}$ turned these gray, and acid leaching in $2.2 \mathrm{M} \mathrm{HNO}_{3}$ at $353 \mathrm{~K}$ for $2 \mathrm{~h}$ turned the wafers white. For all the samples investigated in this study, the wafers remained intact after this treatment, and their physical dimensions remained unchanged.

A more quantitative demonstration of the nickel removal is given in Fig. 1, which shows XRD patterns for the Ni-YSZ cermet made with $50 \mathrm{wt} \% \mathrm{NiO}$ after reducing in $\mathrm{H}_{2}$ and acid leaching. The presence of features associated with nickel and YSZ in Fig. 1(a) demonstrates that the nickel and YSZ exist in separate phases. The

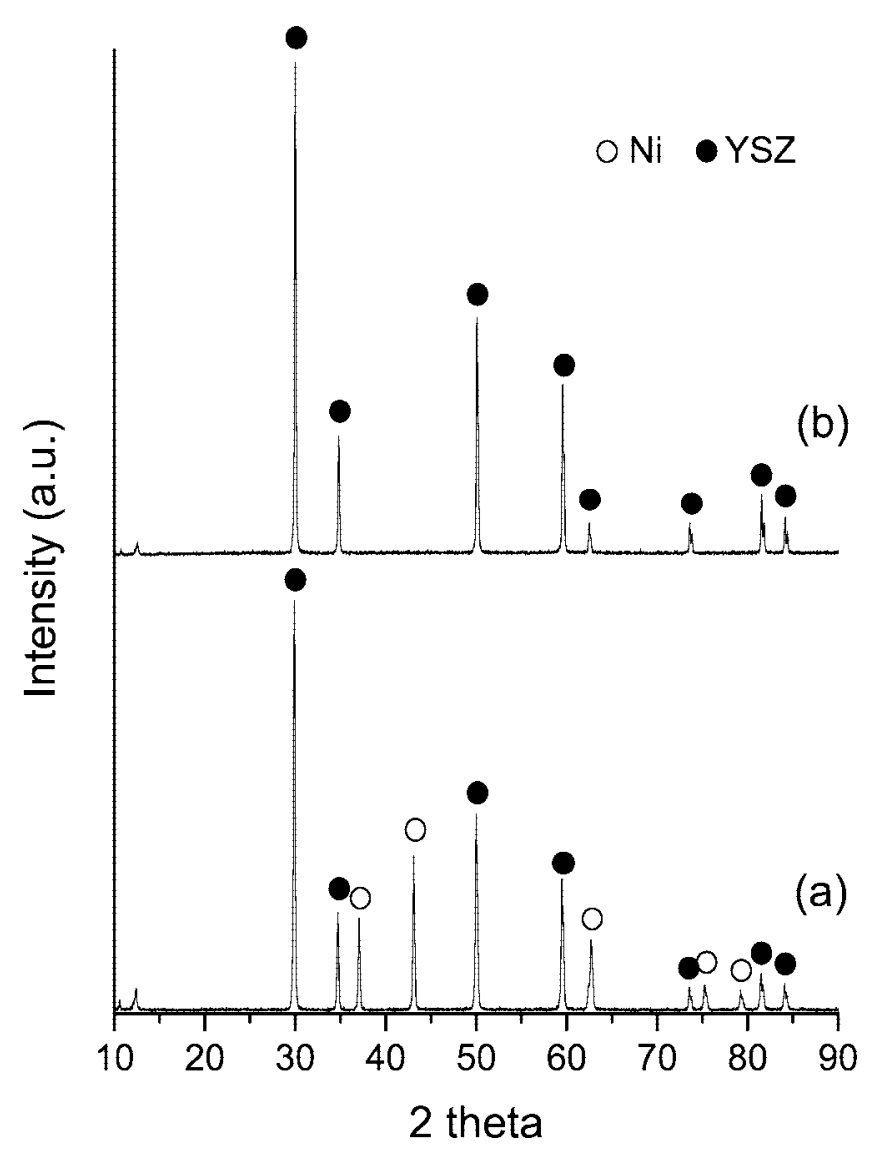

Fig. 1. XRD patterns of the $\mathrm{NiO} / \mathrm{YSZ}$ cermet with ratio of $1 / 1$ before and after leaching in nitric acid. Cermet was prereduced by $\mathrm{H}_{2}$ at $973 \mathrm{~K}$ for 10 h. Data are shown (a) before and (b) after leaching.

\begin{tabular}{lcc}
$\begin{array}{c}\text { Table I. } \\
\text { NiO/YSZ Composites after Reduction and after } \\
\text { Leaching in } \mathbf{H N O}_{3}^{\dagger}\end{array}$ \\
\hline $\begin{array}{c}\text { YSZ/NiO } \\
\text { mass ratio }\end{array}$ & $\begin{array}{c}\text { Fractional weight after } \\
\mathrm{H}_{2} \text { reduction }\end{array}$ & $\begin{array}{c}\text { Fractional weight after } \\
\text { leaching }\end{array}$ \\
\hline $100 / 0$ & $0.999(1.000)$ & $0.999(1.000)$ \\
$80 / 20$ & $0.959(0.958)$ & $0.805(0.800)$ \\
$60 / 40$ & $0.916(0.914)$ & $0.605(0.600)$ \\
$50 / 50$ & $0.894(0.894)$ & $0.501(0.500)$ \\
\hline $\begin{array}{l}\text { Values in parentheses were calculated based on complete reduction } \\
\text { of NiO to nickel and complete removal of NiO. }\end{array}$
\end{tabular}

peaks associated with the nickel phase are completely removed after acid leaching. Based on the detection limits in XRD, we estimate that the sample in Fig. 1(b) contains $<3 \%$ nickel, suggesting that $>90 \%$ of the nickel has been removed.

A more sensitive demonstration that the nickel had been completely removed came from experiments in which we exposed the wafer, whose XRD pattern is shown in Fig. 1(b), to dry flowing methane at $1073 \mathrm{~K}$ for $1.5 \mathrm{~h}$. Nickel particles are known to rapidly catalyze the formation of graphite fibers under these conditions, so that even small amounts of nickel should be observed through the formation of carbon. ${ }^{15}$ In our own work, we demonstrated that a 20 $\mathrm{wt} \% \mathrm{Ni}-$ YSZ cermet treated in this way formed a large amount of carbon in $1.5 \mathrm{~h}$, many times the weight of the initial sample. ${ }^{16}$ However, in the case of the acid-leached sample, we observed no evidence of carbon formation under these conditions. While the sample turned a light gray color after this treatment, the weight change was $<0.1 \%$. Also, an identical color change was observed for a YSZ wafer made without nickel after this pretreatment. This strongly supported the fact that all the nickel had been removed in the leaching process.

Results from the weight and porosity measurements for each of the samples investigated, before and after leaching, are summarized in Tables I and II. While only one set of data are shown, the results from other sample batches were identical within the experimental error of the measurements. Weight changes were reproducible to within $\sim 0.1 \%$, and porosity measurements were within $\sim 1 \%$. In Table I, we listed the changes in the sample mass, after reduction and after leaching in $\mathrm{HNO}_{3}$, as a function of the initial composition of the NiO/YSZ composite ceramics. The values in parentheses in both columns were calculated values assuming complete reduction of $\mathrm{NiO}$ to nickel and complete removal of nickel. No weight change occurred in the $100 \%$ YSZ wafer on reduction or acid leaching, indicating that YSZ was unaffected by this treatment. Based on the low solubility of $\mathrm{ZrO}_{2}$ in acid solutions, this result was expected. By contrast, the weight changes observed in the NiO-containing composites indicated, within experimental error, that $\mathrm{NiO}$ was completely reduced to nickel during $\mathrm{H}_{2}$ reduction and that nickel was completely removed during acid leaching. With the $50 \% \mathrm{NiO} / \mathrm{YSZ}$ ceramic, it was noteworthy that, even though $50 \%$ of the sample mass was removed by reduction and acid leaching, the wafer remained structurally intact.

Table II shows the porosities, as measured by water uptakes, for each of the samples after each of the treatments. Because all the

Table II. Porosities of NiO/YSZ Samples after Various Pretreatment Conditions ${ }^{\dagger}$

\begin{tabular}{lccc}
\hline $\begin{array}{c}\text { YSZ/NiO } \\
\text { mass ratio }\end{array}$ & $\begin{array}{c}\text { Initial } \\
\text { porosity } \\
(\%)\end{array}$ & $\begin{array}{c}\text { Porosity after } \\
\mathrm{H}_{2} \text { reduction } \\
(\%)\end{array}$ & $\begin{array}{c}\text { Porosity after } \\
\text { leaching } \\
(\%)\end{array}$ \\
\hline $100 / 0$ & 33 & $33(33)$ & $32(33)$ \\
$80 / 20$ & 38 & $42(41)$ & $47(47)$ \\
$60 / 40$ & 46 & $54(54)$ & $64(64)$ \\
$50 / 50$ & 51 & $59(60)$ & $69(72)$ \\
\hline
\end{tabular}

†alues in parentheses are calculated from initial porosities, assuming bulk densities for each component and complete reduction of $\mathrm{NiO}$ to nickel and complete removal of $\mathrm{NiO}$. 
samples were made by tape casting with graphite pore formers, the samples were all highly porous even before reduction or leaching. Initial porosity appeared to increase with the $\mathrm{NiO}$ content of the composite oxides, but we could not determine from the experiments performed whether this was fundamental to the NiO/YSZ system or a result of the particle sizes of the powders used in our study. After reduction in $\mathrm{H}_{2}$, no change was observed for the YSZ sample, but a small increase was observed in the porosity of each sample containing NiO. The calculated porosities in Table II, determined from the initial porosity of each sample and the volume change expected for complete reduction of $\mathrm{NiO}$ to nickel, agreed well with the measured values. The porosity changes that occurred on acid leaching were more significant. Again, essentially no change occurred in the porosity of the YSZ wafer. By contrast, the porosity of the $50: 50 \mathrm{NiO} / Y S Z$ composite increased from $51 \%$ to $69 \%$ following this treatment. The calculated porosities, shown in parentheses and determined by assuming that $\mathrm{NiO}$ was simply removed from the structure, agreed well with experimental values.

To check the reliability of the water-uptake measurements, mercury porosimetry measurements were performed on the $100 \%$ YSZ sample and the 50:50 NiO/YSZ composite after removal of the nickel. According to mercury porosimetry, the porosities of the two samples were slightly higher than those obtained by water uptakes, $36.6 \%$ compared with $33 \%$ for the $100 \%$ YSZ, and $76.7 \%$ compared with $69 \%$ for the acid-leached Ni-YSZ. It seemed likely that water-uptake measurements underestimated porosities because of the incomplete filling of large pores in the structure. Of additional interest was the pore size distribution of the two samples, shown in Fig. 2. For the 100\% YSZ sample, median pore size was $1.1 \mu \mathrm{m}$. However, for the leached Ni-YSZ cermet made from the $\mathrm{NiO} / \mathrm{YSZ}$ ratio of $1: 1$, median pore size was $3.6 \mu \mathrm{m}$. Also, the distribution of pore sizes was larger in the leached sample. While the multiple sharp features in Fig. 2 are likely an artifact of the measurements, the distribution of pore sizes was clearly larger in the leached sample.

SEM micrographs were also taken of a 50:50 NiO/YSZ composite after removal of the nickel, with the results shown in Fig. 3 at high and low magnification. SEM confirmed the high porosity of the structure and indicated that porosity was uniform over the entire sample. Typical pore dimensions in the micrographs were also slightly $>1 \mu \mathrm{m}$, in good agreement with mercury porosimetry data.

To determine the suitability of this approach for the fabrication of SOFCs with copper-based anodes, we prepared and tested a cell according to the methods described in Section II. After reducing

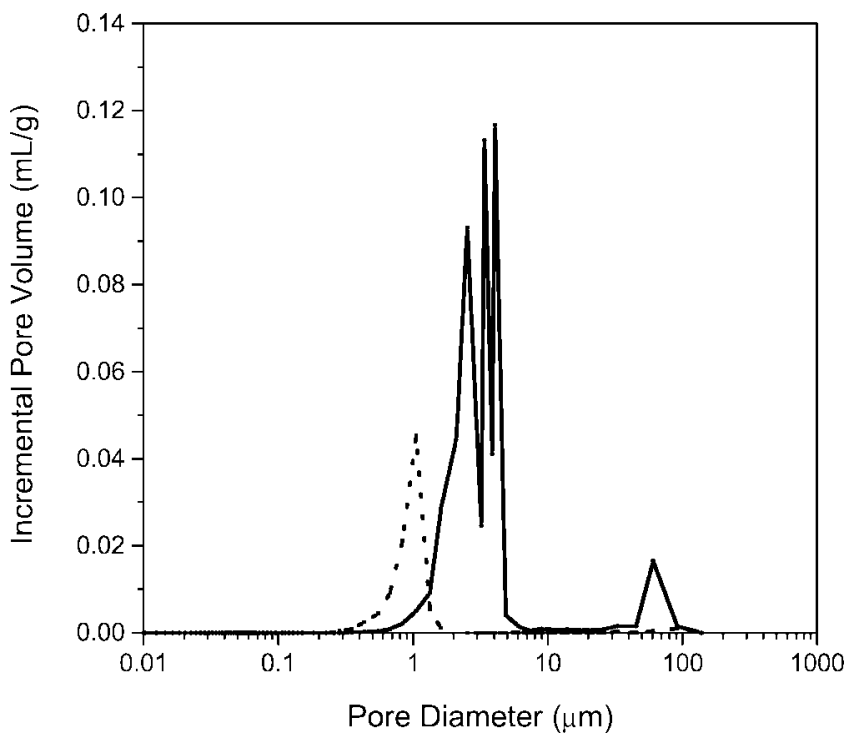

Fig. 2. Plots of pore size distribution of $100 \%$ YSZ and NiO/YSZ cermet with ratio of 1:1 after reduction by $\mathrm{H}_{2}$ and leaching in nitric acid. (- - ) is $100 \%$ YSZ cermet, and (-) is NiO/YSZ cermet with ratio of 1:1.
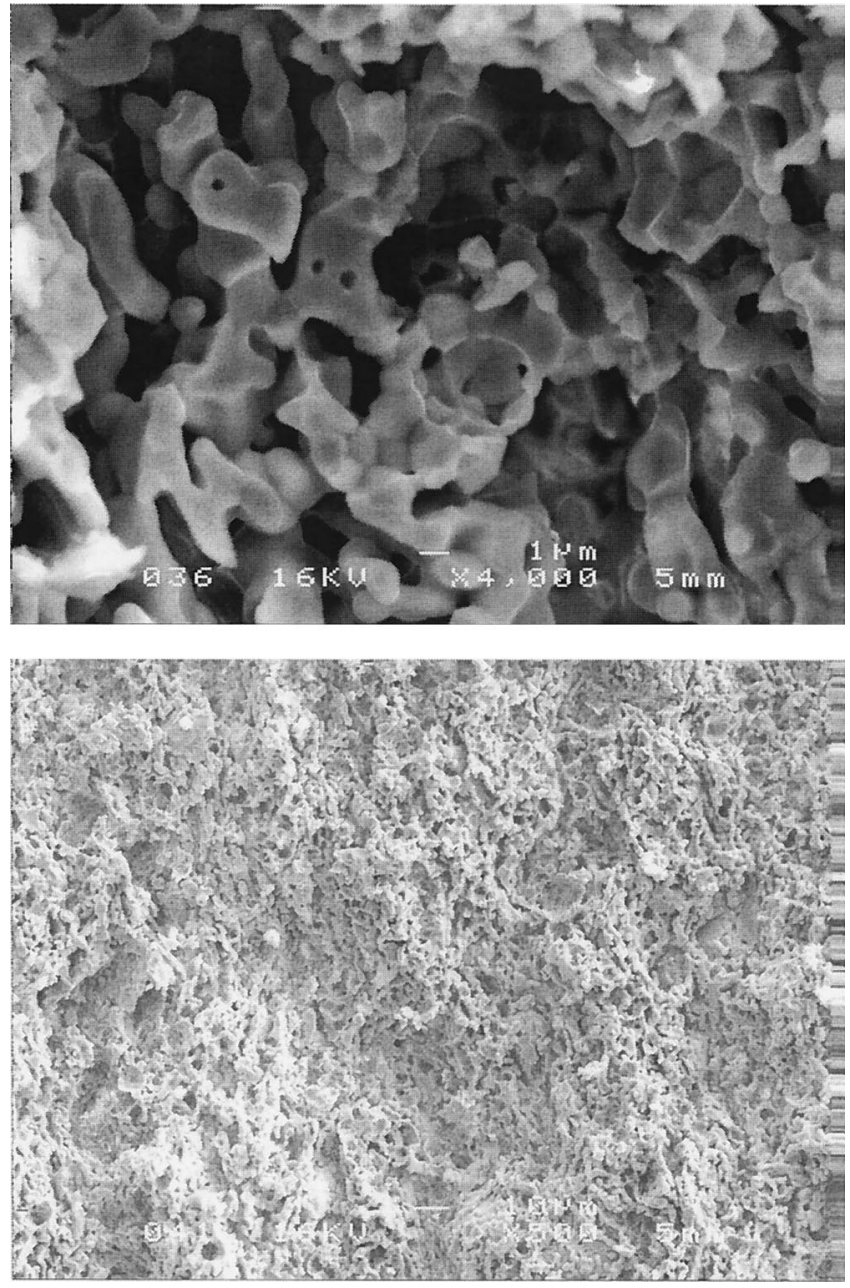

Fig. 3. SEM micrographs of $50: 50 \mathrm{NiO} / \mathrm{YSZ}$ composite after acid leaching.

the anode in pure $\mathrm{H}_{2}$ at $973 \mathrm{~K}$, the performance curves were measured in flowing $\mathrm{H}_{2}$ and flowing $n$-butane, with the results shown in Fig. 4. For $\mathrm{H}_{2}$, the open circuit voltage (OCV) was slightly $<1.1 \mathrm{~V}$, in good agreement with the theoretical Nernst value, demonstrating that the YSZ electrolyte layer had not been damaged by acid leaching. Considering that the electrolyte was a relatively thick $60 \mu \mathrm{m}$, the maximum power density for this cell, $0.26 \mathrm{~W} / \mathrm{cm}^{2}$, was reasonable for operation at $973 \mathrm{~K}$. Of greater interest were the data for $n$-butane. Not only was the $\mathrm{OCV}>1.0 \mathrm{~V}$, the maximum power density, $0.15 \mathrm{~W} / \mathrm{cm}^{2}$, was higher than we had achieved in our previous work on essentially identical cells, with the exception that porosity in the anode had been achieved by pore formers alone. ${ }^{17}$ Furthermore, we observed no evidence of coking due to $n$-butane, further evidence that the nickel had been removed completely.

In addition to demonstrating the use of oxide pore formers for the fabrication of porous ceramics, two important points can be drawn from the data shown in this paper. First, the structure of Ni-YSZ cermets, the standard material for SOFC anodes, appears to be established by the YSZ component. Removal of the nickel does not cause collapse of the structure in our experiments. This should not be surprising, given that there is a good match in the coefficient of thermal expansion of Ni-YSZ and YSZ in SOFCs made with anode-supported electrolytes. Second, the performance of SOFCs with copper-based anodes is strongly affected by the structure of the oxide phase. This system has not yet been optimized. Even so, reasonable performance has been achieved. Optimization of anode structure has given rise to significant 


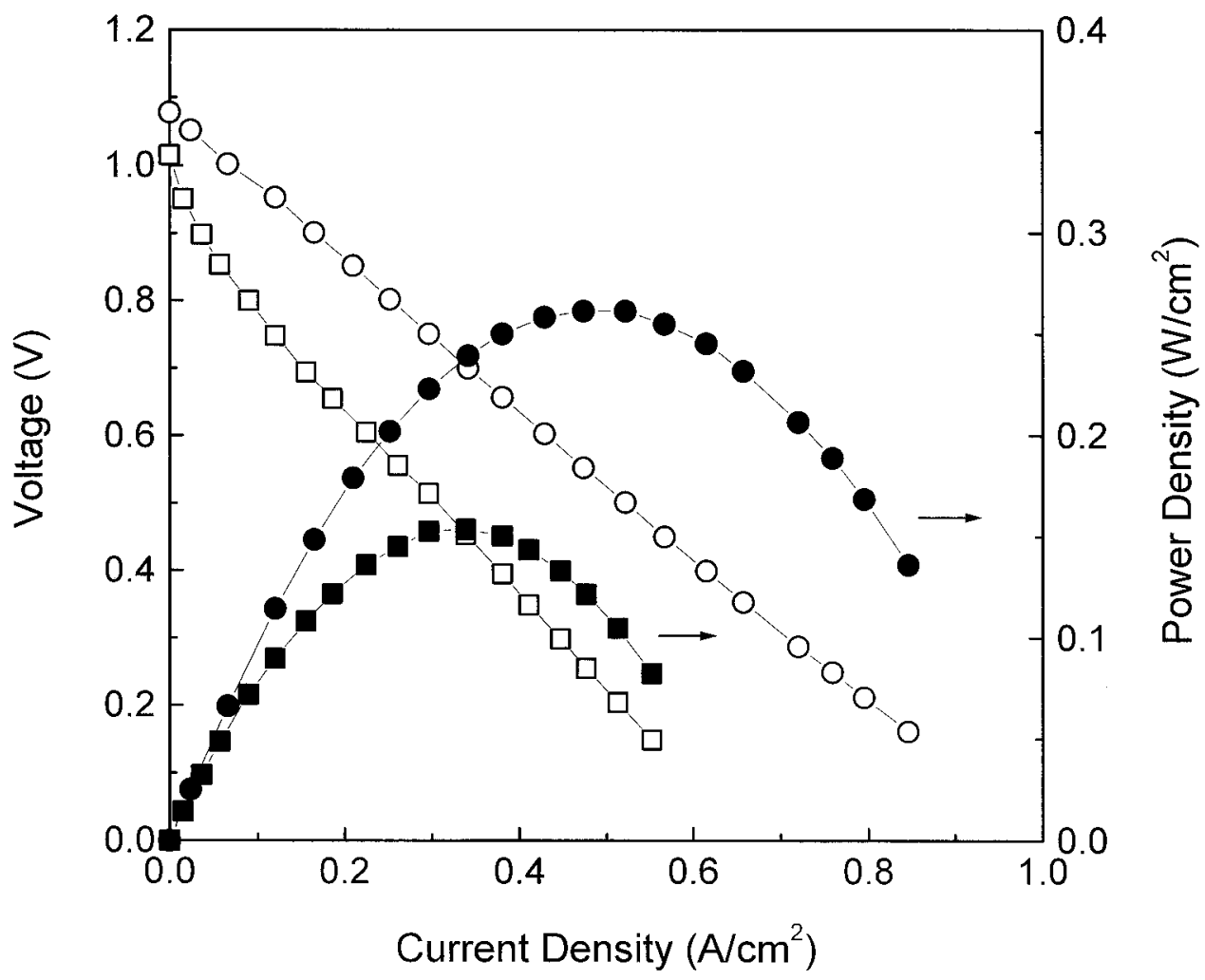

Fig. 4. Plots of cell potential and power density as function of current density for copper-based anode fabricated by exchanging nickel with copper. Operation temperature is $973 \mathrm{~K}$. Data are shown for following fuels: $(\bigcirc, \bullet)$ voltage and power density of $\mathrm{H}_{2},(\square$, $\square$ ) voltage and power density of $n$-butane, respectively.

improvements in the performance of Ni-YSZ cermets, and similar enhancements might be expected for the copper-based systems. ${ }^{12,13}$

\section{Conclusions}

We have demonstrated that highly porous YSZ can be prepared by forming a Ni-YSZ cermet, then leaching the nickel out of the structure with nitric acid. The YSZ phase appears to be completely unaffected by the leaching process.

\section{Acknowledgment}

The authors are grateful to Ford Motor Co. for their assistance.

\section{References}

${ }^{1}$ N. Q. Minh, "Ceramic Fuel-Cells," J. Am. Ceram. Soc., 76 [3] 563-88 (1993). ${ }^{2}$ S. Park, R. Craciun, J. M. Vohs, and R. J. Gorte, "Direct Oxidation of Hydrocarbons in a Solid Oxide Fuel Cell: I. Methane Oxidation," J. Electrochem. Soc., 146 [10] 3603-605 (1999).

${ }^{3}$ S. Park, J. M. Vohs, and R. J. Gorte, "Direct Oxidation of Hydrocarbons in a Solid Oxide Fuel Cell,” Nature (London), 404, 265-67 (2000).

${ }^{4}$ R. J. Gorte, S. Park, J. M. Vohs, and C. Wang, "Anodes for Direct Oxidation of Dry Hydrocarbons in a Solid Oxide Fuel Cell," Adv. Mater., 12 [19] 1465-69 (2000).
${ }^{5}$ R. Craciun, S. Park, R. J. Gorte, J. M. Vohs, C. Wang, and W. Worrell, “A Novel Method for Preparing Anode Cermets for Solid Oxide Fuel Cells," J. Electrochem. Soc., 146 [11] 4019-22 (1999).

${ }^{6}$ A. Mortensen and S. Suresh, "Functionally Graded Metals and Metal-Ceramics Composites: Part 1, Processing," Int. Mater. Rev., 40, 239-65 (1995).

${ }^{7}$ For example, see product specifications from Zircar Zirconia, Inc., Florida, NY 10921

${ }^{8}$ S. F. Corbin and P. S. Apte, "Engineered Porosity via Tape Casting, Lamination and the Percolation of Pyrolyzable Particulates," J. Am. Ceram. Soc., 82 [7] 1693-701 (1999).

${ }^{9}$ T. Nishikawa, A. Nakashima, S. Honda, and H. Awaji, "Effects of Porosity and Pore Morphology on Mechanical Properties of Porous Alumina," J. Soc. Mater. Sci., Jpn., 50, 625-29 (2001).

${ }^{10}$ O. Lyckfeldt and J. M. F. Ferreira, "Processing of Porous Ceramics by Starch Consolidation," J. Eur. Ceram. Soc., 18, 131-40 (1998).

${ }^{11}$ F. F. Lange and K. T. Miller, "Open-Cell, Low-Density Ceramics Fabricated from Reticulated Polymer Substrates," Adv. Ceram. Mater., 2 [4] 827-31 (1987).

${ }^{12}$ M. Brown, S. Primdahl, and M. Mogensen, "Structure/Performance Relations for Ni/Yttria-Stabilized Zirconia Anodes for Solid Oxide Fuel Cells," J. Electrochem. Soc., 147 [2] 475-85 (2000).

${ }^{13}$ H. Koide, Y. Someya, T. Yoshida, and T. Maruyama, "Properties of Ni/YSZ Cermet as Anode for SOFC," Solid State Ionics, 132 [3-4] 253-60 (2000).

${ }^{14}$ S. Park, J. M. Vohs, and R. J. Gorte, "Tape Cast Solid Oxide Fuel Cells for the Direct Oxidation of Hydrocarbons," J. Electrochem. Soc., 148 [5] A443-47 (2001).

${ }^{15}$ R. T. K. Baker, "Catalytic Growth of Carbon Filaments," Carbon, 27 [3] 315-23 (1989).

${ }^{16}$ H. Kim, C. Lu, W. L. Worrell, J. M. Vohs, and R. J. Gorte, "Cu-Ni Cermet Anodes for Direct Oxidation of Methane in Solid Oxide Fuel Cells," J. Electrochem. Soc., 149 [3] A247-A250 (2002).

${ }^{17}$ H. Kim, S. D. Park, J. M. Vohs, and R. J. Gorte, "Direct Oxidation of Liquid Fuels in a Solid Oxide Fuel Cell," J. Electrochem. Soc., 148 [7] A693-95 (2001). 